\title{
Men of War, Men of Peace: Changing Masculinities in Vanuatu
}

\section{Margaret Jolly}

To cite this article: Margaret Jolly (2016) Men of War, Men of Peace: Changing

Masculinities in Vanuatu, The Asia Pacific Journal of Anthropology, 17:3-4, 305-323, DOI:

10.1080/14442213.2016.1191531

To link to this article: http://dx.doi.org/10.1080/14442213.2016.1191531

曲 Published online: 21 Jul 2016.

Submit your article to this journal $₫$

Џ Article views: 46

Q View related articles $\square$

View Crossmark data ¿ 


\section{Men of War, Men of Peace: Changing Masculinities in Vanuatu}

\section{Margaret Jolly}

The first European observers in the archipelago we now call Vanuatu characterised Indigenous men as martial warriors. Such observations occluded the diversity of Indigenous masculinities and the violence inherent in colonial processes of exploration, and later dispossession, 'pacification' and the imposition of colonial law. Indigenous relations between men were grounded in ascribed hierarchies of seniority and either achieved or ascribed hierarchies of divine power. Ideally more senior and higher 'men of peace' were seen to eclipse younger, lower 'men of war', but creative and destructive aspects of masculine power were often co-present in Janus-face formations. In surveying the longue durée of changing masculinities in Vanuatu we can witness complex reconfigurations associated with Christian conversion, the 'labour trade', commodity economy and state politics. The American military presence during the Second World War was a pivotal moment in such historical reconfigurations. As against the colonial masculine hierarchy of white mastas and black boes, it generated idioms of racial equality and fraternity between black men and white men and fuelled movements for independence. This is in stark contrast with the historical experience of another Pacific archipelago, Hawai $i$, a state of the United States and a major base for the US military securing what some Kānaka Maoli see as an occupation of their homelands. A comparison of these two Pacific archipelagos highlights how Indigenous masculinities are historically formed and transformed in the context of the race relations of different colonialisms.

Keywords: Masculinities; Vanuatu; Hawai'i; War; Peace

\footnotetext{
Margaret Jolly is Professor of Anthropology and Australian Research Council Laureate Fellow 2010-16 at the Australian National University. Correspondence to: Margaret Jolly, School of Culture, History and Language, College of Asia and the Pacific, The Australian National University, ACT, 0200 Australia. Email: Margaret. Jolly@anu.edu.au 


\section{The Exploratory Moment: Men of War, Men of Peace}

I believe they are very wretched, on account of the internecine war, of which we were witnesses and which brings great hardships upon them. (Bougainville 1772, 292, writing on Ambae) ${ }^{1}$

The natives of Tanna gave us more than once to understand, that if we penetrated far into the country against their will, and without their permission, they would kill us, cut our bodies up, and eat them. (Forster 1996 [1778], 211)

These quotations from French and British exploratory voyages of the eighteenth century suggest that the men of the islands James Cook called the 'New Hebrides' and we now call 'Vanuatu' were frequently characterised by European observers as valiant warriors and likely cruel cannibals. ${ }^{2}$ Although many of the embodied daily accounts of these European 'discoverers' rather afford examples of Indigenous men acting as welcoming hosts, friendly translators and even peace-makers (see Jolly 1992), in the broad comparative generalisations by writers like Louis de Bougainville, Cook and even Johann Reinhold Forster, caveats and qualifications tend to be evacuated as ni-Vanuatu men were ultimately cast as warriors and cannibals. Such formulations were foundational in later, more essentialist nineteenth-century theories about race and region; traces of such colonial discourse persist today.

There has been a pervasive stress, including in my own writing, on how different figures of women-women of the eastern Pacific versus women of the western Pacific-prefigured the later coagulation of the racial and regional categories of 'Melanesia' and 'Polynesia' in the writings of Dumont d'Urville and others (see Tcherkézoff 2003, 2008; Douglas \& Ballard 2008; Jolly 2009a, 2012). But there were equally strong distinctions made between men, often conforming to the dyadic figures of welcoming pacific friends versus resisting martial enemies. Again these different figures were often regionally differentiated with men in the western Pacific-New Caledonia, Vanuatu, New Zealand and Fiji-more often essentialised as resistant, martial men (see Biersack; Presterudstuen and Schieder this volume). Yet there is abundant evidence that warrior-chiefs were very important in ancient Hawai'i; witness the unification of the islands under King Kamehameha I, achieved as much through wars of conquest from 1782-95 as through diplomacy. Annual cycles in Hawai'i were seen to alternate between the hegemony of the God of War $(K \bar{u})^{3}$ and the God of Peace (Lono) (see Sahlins 1985) and early encounters with Europeans in Hawai'i, like those in Tahiti, occasioned many incidents of mutual homicidal violence (see Sahlins 1985).

From the writings of Forster (2000 [1777]) on Cook's second voyage, through the corpus of Smith (1985) and Dening (1996), it has often been alleged that such performances of 'friendship' occluded the violence of conquest, and offered a palliative view of a pacific Pacific (but see Smith 2010). The textual and the visual material from the three voyages of Cook is replete with characterisations of Hawaiian men, and especially of high-ranking ali'i or chiefs, as valued, intimate friends. On the third voyage, John Webber was enjoined to paint pictures of pacific exchange and joyous welcome in these islands, although obviously his portrayal of The Death of 
Cook (Webber 1779) in Kealakekua Bay at the hands of Hawaiian warriors had to depart from this preferred genre. By contrast, the men of Cook's New Caledonia, New Hebrides and New Zealand, were far more regularly portrayed in drawings, paintings and engravings by William Hodges, as warriors, their bows and arrows or clubs poised to attack, or, as in The Landing at Erromanga, One of the New Hebrides, as violently resisting the landing of Cook's boats (see Jolly 1992). Apart from the perils of such huge generalisations from the evanescent experience of 'discoveries', there is, to use an aquatic riff on a contemporary cliché, 'the whale in the ocean': the European men making such adjudications were armed to the teeth, with muskets, daggers and cannonballs. This state of martial preparedness did not suggest their own masculinity was 'savage', but rather legitimated their sense of both their technical and moral mastery of the arts of war and thus their superiority relative to the 'savages' they confronted (see Jolly 2009b).

\section{Re-membering Oceanic Masculinities, Recuperating Hawaiian Warriors?}

I start with these vignettes from European exploratory voyages to again advance the argument that Oceanic masculinities are best seen as historically produced and relationally constructed (see Jolly 2008a). Diverse and contending masculinities are witnessed not just, for example, in the colonial relations of Māori and Pākehā (white settlers) in New Zealand, Kānaka Maoli (Indigenous Hawaiians) and haole (foreigners), but in the relations between Māori and Kānaka Maoli men as depicted by Ty Kāwika Tengan $(2008$ a, 127) in his influential book Native Men Remade.

That book is a tour de force, in many senses. It is focused on how the figure of the Hawaiian warrior has been deployed in contemporary movements such as Hale Mua which, through the revival of martial arts, bodily disciplines and spiritual practices, has tried to reconnect Indigenous Hawaiian men both to ancient Hawaiian culture and contemporary sovereignty politics. The Indigenous monarchy of Hawai'i was overthrown in 1893 by American insurgents, the islands annexed by the United States in 1898 and then absorbed as a state of the United States in 1959. Many Indigenous Hawaiians lament this history and seek to restore Indigenous sovereignty in some form, though there are complex contests about its political prospects (see Kauanui 2008; Goodyear-Ka'ōpua, Hussey, \& Wright 2014).

Tengan (2008a, 2008b, 2016) situates this diverse movement in the context of the 'feminisation' of Hawai'i (see Kauanui 1998; Ferguson \& Turnbull 1999; Trask 1999), most pronounced in the clichéd figure of the 'hula girl' promoted by mass tourism and, in a powerful reversal of that passive feminine figure, the perceived dominance of Hawaiian women like Haunani-Kay Trask and Mililani Trask in sovereignty politics. Tengan is acutely aware of the several dangers involved in the recuperation of the figure of the Hawaiian warrior: it risks celebrating male violence in Indigenous resistance; it challenges feminist critiques of Hawaiian male domination; and risks overlooking how many Hawaiian men serve in the US military. He deals with such dangers with nuance and acuity but ultimately concludes that such a model of 
masculine cultural virility is crucial in challenging the emasculation inherent in the annexation and the continuing US occupation of Hawai'i. Elsewhere in Oceania, the figure of American 'men of war', long departed since the Second World War, has had a rather contrary influence, stimulating and fuelling anti-colonial nationalisms rather than vanquishing them. Vanuatu is one such place.

\section{The Hegemony of Hegemonic Masculinities}

How does this Oceanic material relate to broader debates about masculinities and, in particular, the hegemony of Connell's (1987) concept of 'hegemonic masculinities'? It denotes not the statistical norm but the 'most honored way of being a man' (Connell \& Messerschmidt 2005, 832). As Connell and Messerschmidt suggest, hegemonic masculinity does not 'correspond closely to the lives of any actual men' but rather 'express[es] widespread ideals, fantasies, and desires' (838). Connell's concept has proved productive in research on men and masculinities across Oceania: in nationalist struggles and movements for cultural revival (Jolly 2008b; Walker 2005; Tengan 2008a, 2008b); in the context of world wars and continuing militarism in the region (Dvorak 2008; Camacho \& Shigematsu 2010; Camacho 2011); in studies of Hawaiian and Māori players of football and rugby (Hokowhitu 2004, 2008; Tengan \& Markham 2009); and apropos men who identify as homosexual or gay and the diverse regional expressions of gender crossing (George 2008; Besnier \& Alexeyeff 2014; Teaiwa 2014; see Schmidt this volume).

Here I consider changing masculinities in Vanuatu (see Taylor 2008b). ${ }^{5}$ In much earlier ethnography and history the study of men predominates, even if the concepts, practices and values of diverse masculinities are somewhat under-theorised or theorised through the use of a functionalist, evolutionary or psychoanalytic lens (see Layard 1942; Allen 1981, 1984; Jolly 1991 for a critique). ${ }^{6}$ I suggest that contrary to early European impressions, it was not so much 'men of war' as 'men of peace' who embodied hegemonic masculinity in the diverse Indigenous cultures of north Vanuatu. Further, I suggest that the combined effects of colonial pacification, Christianity, indentured and wage labour, state-based politics, and especially the extraordinary experiences of the Second World War, all of which entailed close relations between ni-Vanuatu and foreign men, dramatically reconfigured Indigenous models of masculinity in complex and sometimes contradictory ways.

Here, my argument must perforce be suggestive and telegraphic. I first distil what I discerned about the relation between 'men of war' and 'men of peace' through ethnographic research in the kastom villages of South Pentecost in the 1970s. I then move scales to consider more broadly the combined and somewhat complicit effects of colonial pacification and Christianity throughout the archipelago. Third, I ponder the effects of circular male labour migration on both gender and generational relations. Fourth, I reconsider the extraordinary events of the Second World War and relations between Indigenous and American men. In conclusion I ponder how women were physically and semiotically marginalised in the long history of these male-male 
relations born of colonialism and modernity and the effects these deep historical transformations might still exert in the contemporary configurations of masculinities.

\section{An Ethnographic Moment: Kastom in South Pentecost in the 1970s}

Pentecost. Bougainville so named this island on Whitsuntide, 1768, on his quick trip through the archipelago. If he had made landfall on Pentecost, Bougainville (1772, 292) would likely have found the 'natives', as on Ambae, engaged in acts of 'internecine warfare'. Nearly 200 years later, these islands had been 'pacified' but I recorded oral histories from several older men who related with some relish to a wide-eyed young woman from Australia the gruesome details of violent raids, ambushes, full frontal battles and cannibal acts based on their own experience as young boys in the 1920s and the eyewitness accounts of older men who had since died. Two highranking older men, Tawas Molga and Tawas Meleun, in particular described protracted wars in the 1920s and early 1930s.

Men, women and children were all victims of such warfare, which typically erupted over disputes about the use of land for gardens, the movement of pigs and the flow of women in marriage. Warriors, bwari in the local Sa language, were thought to embody a hot, fiery form of masculinity, qualities most pronounced in young men. Older, highranking men were engaged in acts of war not so much as warriors or fight leaders but as strategists, diviners and spiritual guides.

But, as Tattevin (1926-27) attests, and I observed fifty years later, after effective colonial pacification, quotidian, consequential power for men of all ages derived primarily from the rituals of taking titles in 'the graded society', in which pigs, not people, were sacrificed (see Jolly 1994, 173-210). Bougainville thought the slit gongs of Ambae were 'war drums' and the enclosures around villages 'fortifications'. But, in late twentieth-century Vanuatu, the low stone enclosures around villages and gardens were rather fences to keep pigs out, and slit gongs most often resounded in complex rhythms marking the sacrifice of pigs and the exchange of pigs and pandanus textiles in rituals whereby both men and women attained titles and accumulated sacred power (konan). In the past, the power of high-ranking men entailed the power to make peace between warring neighbours and was thought to transcend the more transient violent power of younger warriors. In an annual cycle reminiscent of that in ancient Hawai' $i$, in certain months of the year, when ceremonies were at their peak, peace prevailed; in other months warfare was ascendant. By the time of my doctoral fieldwork in the 1970s, high-ranking men were still seen as powerful peace-makers in local disputes and some had assumed a colonial mantle of legitimacy as 'assessors' or 'chiefs' authorised to preside over local village courts and resolve conflicts through harmonious resolutions or wise adjudications (see Jolly 1994, 49-51, 211-245).

Following Connell and Messerschmidt (2005, 832), I contend that the 'most honored way of being a man', for ni-Vanuatu in the late twentieth century was embodied in the figure of men of peace, not men of war. This dyad was connected to the idealised relations of the elder brother and the younger brother (see Jolly 1994). ${ }^{7}$ In 
narratives of origin (dun na ngamômô) and stories of movement of people across the landscape (dun na buluim), the power of the senior, elder brother habitually eclipses that of the younger brother. Their relation is often represented as the relation between a benevolent creative being and a peace-maker versus a malevolent trickster, full of restless energy, sexual desire and agonistic spirit. In origin stories this is canonically portrayed in the relation between the eldest brother Barkulkul (literally 'the great big one') and Marelul (literally 'Moonlight'), the younger brother who has adulterous sex with Barkulkul's wife, and plays violent pranks on him. But ultimately Barkulkul triumphs over his younger brother. Enticing him to engage in the canonical collective fraternal work of planting long yams in deep holes, Barkulkul kills his younger brother and buries him like a long yam. At this point Barkulkul patently ceases to be a 'man of peace'; his fratricidal act occasions human death and precipitates his departure from the world of the living (see Jolly 1994). So Barkulkul has a Janus face, a dark side. I earlier suggested (Jolly 1996) an irony in how the Marist priest Elie Tattevin translated Barkulkul as God. But perhaps Barkulkul's ambivalent character as a benevolent, peaceful, forgiving creator and as a wrathful avenger, punishing sin with death, consummately evokes the Janus face of the introduced Jehovah (see Taylor 2010, 2016).

This Janus face of divine power also characterises living men. Men who have attained elevated titles in the Indigenous hierarchy (warsangul) are thought thereby to have enhanced power to create fertile crops and pigs, nurture healthy children and also to settle disputes and make peace (see Jolly 1994). But their power also has a life-threatening, dangerous dimension. Prior to colonial control, they could kill those men or women who infringed their privileges or who broke the taboos they placed on certain fruit trees and fishing spots. On Ambae, until the mid-twentieth century, groups of young men were the henchmen, violent thugs or sorcerers dispatched by high-ranking elders against their enemies (Allen 1981). Thus, the potentially homicidal power of these 'men of peace' was enacted by those younger 'men of war' who were their agents.

\section{Pacification and Christianity}

When in around 1906 the conjoint colonial powers Britain and France assumed the legitimate monopoly of force and homicidal violence in a process ironically called 'pacification', the power of men of war was thereby curtailed. From the mid-nineteenth century, another kind of 'men of war' had appeared in the archipelago: foreign battle ships whose captains took revenge on those who had allegedly killed white labour recruiters or missionaries, often by indiscriminately shelling entire villages (see MacClancy 1980, 50). Later colonial military tactics involved ambushes and armed raids perpetrated by the conjoint military operations of the British and French-to quash Indigenous resistance, to vanquish attempts to revive a kastom eviscerated by Christian conversion and to forcibly dissuade the adherents of anti-colonial millenarian movements, labelled 'cargo cults', like the famous John Frum movement on Tanna (see Lightner \& Naupa 2005; Tabani \& Abong 2013). 
But the historical hegemony of 'men of peace' over 'men of war' was also dramatically reinscribed by pervasive conversions to Christianity, starting in the southern islands with the arrival of the London Missionary Society in 1839. Those men who became leaders of the Christian churches, the indigenous catechists, pastors and priests, were, rhetorically at least, cast as 'men of peace', proponents of a new religion that promised salvation through the warm embrace of Christ's love and through eschewing violent sins: war, sorcery and gender violence. By contrast those men who pursued the kastom road were cast as belligerent opponents by colonial and Christian authorities, pursuing war against both the Christian converts in their communities and the Condominium government. The hierarchy of leaders in the Christian churches was often likened to the Indigenous hierarchy of male titles (see Taylor 2008a, 117), and such men became crucial in settling disputes, making peace or inviting the colonial authorities to do so.

Yet, some recent ethnographies of North Vanuatu suggest that the power of such Christian leaders was not always so pacific and benign in practice (Hess 2009; Taylor 2010, 2016) and that some Anglican Melanesian Brothers, for example, were credited with dark, menacing and malevolent powers, akin to sorcery. Thus, although the Christian churches were overtly associated with the revalorisation of the figure of the 'man of peace', this novel divine power could conceal a dark side-if not overt violence, the covert menace of nakaemas or sorcery.

\section{The Labour Trade: Stilim Man?}

Simultaneous with the spread of Christianity throughout the archipelago was the development of indentured and then wage labour on overseas plantations in Queensland, New Caledonia and Fiji. This was equally crucial in the reshaping of masculinities. Young single men (even boys), some married men in their twenties and a tiny minority of women were recruited (see Moore 1985; Jolly 1987). The 'labour trade'-or, as Shineberg (1999) preferred it, the 'people trade'-has been much written about and fiercely debated (Moore 1985; Jolly 1987; Banivanua-Mar 2007). These historical experiences, predominantly of young men, proved vital in shaping desires for foreign commodities, in developing ideas about labour and white mastas, in preparing the ground for Christian conversion and in dramatically altering both gender and generational relations in the villages of Vanuatu. Both Moore (1985) and Keesing (1986) offer important insights.

First, insofar as the labour trade was sometimes a matter of voluntary recruitment rather than sheer kidnap and coercion, it was the 'free will' of senior men who enjoined young men to sign on, so as to secure the goods that were the benefits of such perilous overseas voyages and years of long, hard labour: steel axes, machetes, cloth and Snyder rifles. Rifles were soon deployed both in the 'internecine' wars of the archipelago and against white colonisers: Snyder rifles were the weapons of choice in early twentiethcentury Vanuatu, just as AK47s are the preferred weapons in 'tribal fighting' in Papua New Guinea today. They were also signs of status and youthful masculine bravado. 
The labour trade, alongside mission stations and circuits, was the conduit through which foreign goods entered as objects of use and exchange in islands across the archipelago. In South Pentecost, the foreign wealth secured through indentured and later wage labour entered into the exchanges of life crisis rituals and especially in the payment of 'bride price' (by the late 1930s; see Jolly 2015). Axes, machetes, tinned fish, cloth and money flowed in tandem and increasingly replaced Indigenous valuables such as pigs and pandanus textiles. Significantly, these goods were primarily procured through the labour of young single men in distant islands, not through the combined labour of mature men and women in their home villages. Young men returning from labour trips did not retain control over the wealth they earned thereby, but such commodities and the associated meanings of modernity were strongly linked semiotically to flashy, fiery, mobile young men (see Macintyre 2008). Those who would in the past have been the bwari, warriors serving the strategic and political interests of high-ranking older men, were increasingly on the front lines of a newly disciplined 'labour', answerable to the white mastas they thought demanding and often cruel, working hard in an emergent capitalist economy.

Second, as well as reshaping extant relations and powers between older and younger men within island communities, the labour trade was crucial in fostering a sense of inter-island connections between young men. Keesing (1986) thought this 'plantation culture' simultaneously fostered ideas of sameness and difference for the young men involved: a pan-Melanesian sense of the commonality of ancestral culture and the shared experience of the pleasures and perils of modernity; and on the other hand a perception of the diversity of island cultures, fostered in colonial labels of ethnicity such as Man Tanna, Man Malaita, and so on.

Third, beyond the momentous experiences of the overseas labour trade, young men continued to be involved in indentured labour contracts and later wage labour on copra plantations throughout the archipelago, and on the islands of Efate and Espiritu Santo in particular. So it was in South Pentecost. Until independence in 1980 (which occasioned the departure of many foreign planters), large groups of young men from proximate villages signed on to work for several months together, usually when the demands of subsistence gardening were less intense. Such labouring experiences were vividly recalled, the idiosyncrasies of various British and French mastas celebrated or lamented, but always mercilessly satirised. Work stories punctuated their life narratives, amplifying their authorship of an individuated life in a way dissimilar to women, who had for the most part not ventured far from the island. ${ }^{8}$ A novel masculine self developed in these intense and fraught relations between white male mastas and their native boes. ${ }^{9}$

Moreover, many young Christian men left home villages to pursue education and employment in the burgeoning towns of Vila and Luganville or overseas, including those who became leaders of independence such as Walter Lini, Donald Kalpokas and Sethy Regenvanu. Thus, in successive generations, from the nineteenth through the twentieth centuries, more independent younger generations of men with far more experience of the world challenged not only the power of senior generations 
of men, but increasingly the local, parochial values on which earlier male hierarchies were founded. Such cosmopolitan experiences were typically mediated by established colonial relations between mastas and boes, but the experiences of the Second World War radically transformed this.

\section{Taem Blong Faet}

No copra here, the new product was war. (Lindstrom 1990, 395)

The experiences of the Second World War when thousands of ni-Vanuatu men worked in 'Labor Corps' for the United States military, were arguably the most momentous in the relational history of masculinities in Vanuatu. The writings of Lindstrom, Gwero and White afford a sharp, critical lens on this period. The archipelago of Vanuatu was not the site of major battles against the Japanese as occurred in the Solomons and Papua New Guinea, including Bougainville, but rather housed staging bases.

On 4 May 1942, the American fleet arrived in Mele Bay, Port Vila, Efate, organised in battle formation in anticipation that the Japanese had already invaded. The size and speed of the American occupation was staggering: artillery posts were established at Pango lighthouse and Devil's Point, the Courthouse and waterfront houses were taken over, the new airstrip of Bauerfield was constructed on erstwhile plantations at Tagabe and a Navy Hospital was erected at Bellevue plantation. Heavy bombers and light fighters took off for gruesome battles in Guadalcanal. As the war moved north, this initial base on Efate was dwarfed by the establishment on Espiritu Santo of an

enormous major aviation and supply base, the size of a small Western city: three bomber airfields ...; two fighter airstrips; patrol torpedo boat maintenance and repair shops; an immense Navy yard; over 50 kilometres of roads; six wharves; a comprehensive telephone system ... aircraft hangars, offices, camps... tennis courts, sports grounds. (MacClancy 1980, 107)

Lines of Quonset huts accommodated the troops: 100,000 men (and a few women) were permanently stationed there, and over half a million passed through during the course of the Pacific War.

These troops urgently required unskilled labour to assist with unloading cargo, washing uniforms and working as domestic servants. Approximately 10,000 Vanuatu men (MacClancy 1980, 109), first from Efate and Tanna and later from West Ambae and other northern islands, were employed on ninety-day contracts, receiving relatively high wages compared to those prevailing in the Condominium. As in Papua New Guinea and the Solomons, there were disputes between the colonial authorities and the American military. In Vanuatu, through Condominium regulations, colonial authorities tried to restrict the number of workers, the length of contracts and the wages offered (thus protecting the local colonial labour market). They also tried to regulate informal interaction with the troops and the circulation of dangerous, anti-colonial knowledge (Lindstrom 1989, 399). These attempts largely 
backfired. The Americans swiftly moved to usurp recruitment and supervision of workers (400), and the Americans promptly gained a reputation among ni-Vanuatu for being not only immensely wealthy and powerful but generous and familiar, unlike other mastas.

These ni-Vanuatu men were subjected to long work hours and a martial discipline that was even more extreme than that which prevailed on colonial plantations: tenhour day or night shifts, one day off a fortnight, uniforms and dog tags. But, unlike the conscription of workers by the Australian New Guinea Army Corps, Tannese and other ni-Vanuatu men eagerly signed up. They were intrigued by their encounters with advanced technology and martial machinery: bulldozers, air planes, radar, telescopes and telephone systems (Lindstrom 1989, 395, 407, 409). And, in addition to higher wages, Americans were generous with gifts of food, clothes, cigarettes, housing, transport, medical care and entertainment. The several oral histories Lindstrom recorded with Tannese veterans of the Labor Corps, such as the leader Nouar, suggest that the food offered by British and French settlers was meagre and poor: 'Fiji taro and rotten bananas, woody manioc ... stinking salt meat' (403). But Americans fed ni-Vanuatu with rice, fruits and diverse foods. 'When America fed us, men ate but couldn't finish it all' $(403,409)$.

Moreover, Americans did not maintain colonial habits of spatial segregation, but often worked in partnership, sharing food and jungle juice (home brewed alcohol) and relaxing together with Indigenous men (despite the increasing medical panics about the spread of malaria and filariasis). These more familiar relations are evidenced in wartime photography (Lindstrom \& White 1990) commissioned by the US army, which indubitably has a propaganda component. But intimate relations with American men were also emphasised by ni-Vanuatu oral historians. Ni-Vanuatu men recollected that Americans called them not just boes, but by Anglicised first names (Joe, Dick, Jimmy) and that although they called their American bosses mastas, Americans sometimes called them 'brothers'. This perception of fraternity was no doubt enhanced by the large numbers of African-Americans amongst the troops: 3400 of the landing force of 4612 on 4 May 1942 were from the black Twenty-Fourth Infantry regiment, part of the segregated army (and they constituted 50-70 per cent of all those who subsequently passed through Efate; Bennett \& Wanhalla 2016, 120). Increasingly AfricanAmericans were seen working in combat roles in the Army and the Navy and also as engineers, truck drivers and so on. Speaking with Lindstrom, Nouar recalled that black men in particular 'called us "brother". Brother, their brothers. They didn't say that we were no good. They liked us, and because of this our hearts were happy with them. Eh, the Americans' (quoted in Lindstrom 1989, 412; Lindstrom and Gwero 1998).

These wartime experiences were told and retold and powerfully moulded niVanuatu masculinities for that generation. Witness the narratives of the famous John Frum movement on Tanna, labelled by many as a 'cargo cult' (see Tabani \& Abong 2013). ${ }^{10}$ The first sighting of John Frum precedes the landing of the American forces in 1942 by six months, but the arrival of the Americans was construed by many Tannese as the fulfilment of John's prophecy (Lindstrom 1990). Tannese men were 
thus eager to work for the Americans. John's message became increasingly anti-colonial, opposing Christianity and the Condominium and advocating a return to kastom, drinking kava and dancing. John Frum's son was said to have gone to America to bring back the king. And successively, in various manifestations of this movement to the present, the USA has been seen not just as the source of future power and wealth for men but as mysteriously linked to the power of the place of Vanuatu and the departed ancestors (Tabani 2008a, 2008b; Lindstrom 1993; Jolly 2013).

Across the archipelago, in various ways Indigenous stories about the departure of the primordial creator beings and the origins of death have become articulated with the story of the Americans. Moltare, the guardian of wisdom and knowledge on Ambae, was said to have been kidnapped by the Americans and his powerful knowledge stolen (Abong 2013). In South Pentecost, men told me that the Americans came from the north east, from the same direction in which Barkulkul, the original creator being, the elder brother of mankind, departed to the skyworld, and that African-Americans were the more fortunate descendants of their departed ancestor. This was not just mythic speculation but clear-sighted conviction. As I was departing to the airport at Lonoror in 1973, Tawas Molga told me that a black American was expected to arrive on a plane and that I should record his genealogy so we could prove that his ancestors came from 'here' (South Pentecost). On my return I had to confess to him that I had failed: the man who had landed at the airport at Lonoror was not an AfricanAmerican but a Tanzanian, engaged in political conversations with leaders of the burgeoning independence movement, at that point influenced by 'Melanesian socialism'.

In both local and national memory work the relations between men of different races in the Second World War proved pivotal. Powerful and wealthy Americans were strongly distinguished from the waet men of Britain, France and Australia. The American commanders, though allied with Condominium authorities to oppose 'cargo cults', acted in ways that stressed their difference from these authorities and often showed their bemusement and contempt for the Condominium, as in the extraordinary events at Million Dollar Point. When his troops were about to depart from Santo in 1945, the American commander offered to sell much of their remaining equipment and tools to the Condominium authorities at a minimal price. The latter demurred, perhaps hoping to secure all this bounty for free. The American commander then precipitously ordered that earthmoving equipment, jeeps, ten-ton trucks, tanks, mobile canteens loaded with tons of equipment be hoisted on cranes and, engines still running, driven into the sea from this point. Ever since, this extraordinary treasure, along with the wreck of the President Coolidge, constitutes underwater cargo for diving enthusiasts (see MacClancy 1980, 110; Lightner \& Naupa 2005, 74-75, 7778).

As elsewhere in the western Pacific, historical experiences and idealised fantasies of the American soldiers became crucial in movements for decolonisation and independence. The previous Director of the Vanuatu Cultural Centre, Marcelin Abong (2013), reflects on this in his recuperative history of Nagriamel: 
Let us remember, with great respect, our ancestors' travels along the sad path of humiliation.... Their mistake was being Melanesian, being black-and claiming their rights. $(82-83)$

For him [Jimmy Stevens, the leader of Nagriamel], America was not a mythical country where cargo comes from, but rather represented the awakening of a political conscience spurred by the presence of the US military in the New Hebrides during World War II. America had become the imagined source of equality and fraternity. (80, my emphasis)

That fraternity was with both black and white American men.

\section{Racial Equality and the Discourse of Fraternity}

In conclusion, I reflect on how racial equality has been imaged through this discourse of fraternity. Women are tellingly absent from this story; racial equality it seems is about parity between men. Women rarely feature in stories about the Second World War. They were not employed by the Americans, even as domestic servants, and the stories about their relations with American men are few and rather vague in the oral histories recorded by Lindstrom (but see Bennett \& Wanhalla 2016). ${ }^{11}$ Women appear occasionally as sexualised mirages of overwhelming American male desires. In Nouar's narrative, for instance, 'They were good men, but they wanted women. They searched for women. They asked us where they could get women. But there were no women' (Lindstrom 1990, 12). But, according to some rare colonial documents and oral histories recounted by ni-Vanuatu women more recently, there were sexual relations between American men, black and white and ni-Vanuatu women, both coerced and consensual and several children were born of such unions (Bennett 2016).

In those earlier male narratives, the 'Americans' have become the hypostatised figures of a hegemonic masculinity: virile, powerful, wealthy, generous, kind even in the midst of gruesome military campaigns. Arguably Americans represented, not just for these old men but for some of their sons, the 'most honored way of being a man' (Connell \& Messerschmidt 2005, 832). As Connell and Messerschmidt suggest, such hegemonic models of masculinity may not 'correspond closely to the lives of any actual men' but rather 'express widespread ideals, fantasies, and desires' (838). The soldiers of a foreign occupying force were converted not just into Allies but long-lost brothers and hopeful figures of a fantastical future of power and wealth for a generation of ni-Vanautu men.

This trope of brotherhood plays on some powerful Indigenous ideas and narratives about male siblings. But, as we have seen in Sa narratives from South Pentecost, brothers are not equals but arrayed in terms of seniority, albeit a seniority that is often threatened by conflicts over status and authority, over the right to command resources and especially over women. Unlike British, Australian and French men who were primarily seen through the colonial hierarchical lens as mastas over Indigenous boes, Americans were thought to be 'brothers', perhaps elder brothers, certainly more powerful and 
wealthy and ultimately evincing an idealised martial masculinity. But as Abong (2013) suggests, the hegemonic masculine presence of Americans in the Second World War was not just a fantasy but fuelled anti-colonial movements which had been simmering for decades, and ultimately erupted in movements to reclaim the land and assert Indigenous citizenship which culminated in the Independence of the archipelago in 1980 as Vanuatu ('land standing up/forever').

\section{Comparative Thoughts}

A more extended comparison with the historical experience of Hawai' $i$ would prove fascinating. Here American soldiers were not an evanescent presence which stimulated Indigenous independence movements but a permanent military force which, for many Kānaka Maoli, is the violent face of the occupation of their homelands. The idealised figure of the 'man of war' or Hawaiian warrior is also deployed in the service of the US military which employs many Hawaiian men and which celebrates the Indigenous veterans who worked in the early intelligence operations in the Pacific (Tengan $2008 \mathrm{~b}$ ) and who died or survived the trauma of the shelling of Pearl Harbor. War memories are a crucial part of the imperial history of the US in Hawai' $i$, and dominant narratives enacted in performances at Pearl Harbor and Punchbowl Cemetery embrace Kānaka Maoli men as fraternal citizens (see White 2001, 2004). But, as Tengan graphically shows, idealisations of Hawaiian warriorhood are also pervasive in the movements of resistance to US imperialism and in diverse parts of the sovereignty movement (2008a, 2016).

If we broaden the comparison beyond the archipelagos of Vanuatu, an independent sovereign state, and Hawai' $i$, an occupied territory, a state of the global superpower of the United States, we might see complex relations between the character and intensity of internal conflicts, how that state is situated in global geopolitics and how far hegemonic masculinities are focused on war rather than peace. Other essays in this volume (especially Presterudstuen and Schieder) stress how the reanimated salience of warriorhood in Indigenous masculinities in Fiji has been fuelled both by the violent conflicts associated with a series of coups and the prominence of Indigenous Fijians in armies active not just at home but in global theatres of war in the past and presently in several missions as UN 'peace-keepers' (see George 2008; Teaiwa 2014). Elsewhere others stress how earlier colonial portrayals of 'martial men' in the western Pacific have underwritten more recent views of raskols, police and security guards in Papua New Guinea and Solomon Islands as essentially and exceptionally violent (see Dinnen 2001; Fry \& Kabutaulaka 2008; Lusby n.d.). By contrast with Fiji, and other independent states of the western Pacific, like Solomons and Papua New Guinea, Vanuatu has, since the struggles for independence, experienced little violent internal conflict. The struggles between nationalist and secessionist movements like Nagriamel in the period around independence did lead to violent clashes and some deaths and forces from Papua New Guinea were brought in to secure the state and effect peace. But the contemporary tensions around land shortages and dispossession, and the 
unequal benefits of modernity in power and wealth have more often resulted in deaths attributed to nakaemas sorcery rather than violent physical confrontations between men. Young men are exposed through cinema, television and digital media to global warrior figures like Kung Fu heroes and Rambo, and can mimic these figures or don the battle fatigues of a global consumerist masculinity or a black American resistance, even as they struggle to positively find their place in towns like Port Vila (Kraemer 2013). But the hegemonic masculine models of older 'men of peace', of jifs, pastors and priests, continue to prevail, even as their hegemony hides a darker side of masculine power and sometimes even perilous violence (see Forsyth 2009; McDonnell 2015).

\section{Acknowledgements}

I thank colleagues in my Australian Research Council-funded Laureate Project Engendering Persons, Transforming Things: Christianities, Commodities and Individualism in Oceania (FL100100196) for their continuing enthusiasm and support. For comments and criticisms on several versions of this paper I thank Martha Macintyre, Aletta Biersack, John Taylor, Rocco Weglarz, those present at sessions of the Association for Social Anthropology in Oceania and the two anonymous readers. I thank Nicholas Mortimer for assistance with powerpoint presentations and Carolyn Brewer and Diana Glazebrook for editing assistance at several points. All remaining errors and infelicities are mine.

\section{Funding}

This work was supported by the Australian Research Council [FL100100196] and the Australian National University.

\section{Notes}

[1] See Jolly (2009b) for a more detailed appraisal of Bougainville's short sojourn in the archipelago where Ambae was his only landfall.

[2] Until Independence in 1980 the archipelago was called the New Hebrides/Nouvelles-Hébrides but I use Vanuatu anachronistically here for clarity, consistency and ease.

[3] But see Tengan (2016) on how this bald translation of this deity or akua reduces the complexity of Kū.

[4] In case this is not obvious, the cliché is 'the elephant in the room'.

[5] See also Eriksen (2008) on changing gender relations in Vanuatu and Kraemer (2013) on young men in Port Vila.

[6] This critique might also be made in relation to earlier ethnography in the Solomon Islands and Papua New Guinea, although later writings (too many to cite here) redress this. See Biersack in this volume.

[7] Similar constructions of fraternal rivalry, especially between elder and younger brothers, are pervasive in both oral traditions and embodied experience in other islands of Vanuatu and indeed in many parts of the Pacific.

[8] This was and is characteristic of kastom villages but in Christian villages girls often travelled as girls to schools and women to jobs on plantations or in port towns. 
[9] The colonial language of mastas and its infantilising counterpart boes is still heard in Bislama the pidgin spoken in Vanuatu, but often is used to satirise, criticise or subvert unequal relations between men

[10] There is no space to detail affinities in ideas of Americana and white men in 'cargo cults' in PNG and the Solomons.

[11] Bennett and Wanhalla (2016) and a related film Born of Conflict uncovers the untold stories of intimate sexual relations between Pacific women and American servicemen and the children born of such encounters.

\section{References}

Abong, Marcelin. 2013. "Metamorphoses of Nagriamel." In Kago, Kastom and Kalja: Old Theories and New Realities in the Study of Melanesian Movements, edited by Marc Tabani and Marcelin Abong, 42-60. Marseille: Pacific-CREDO Publications.

Allen, Michael R. 1981. "Innovation, Inversion and Revolution as Political Tactics in West Aoba." In Vanuatu: Politics, Economics and Ritual in Island Melanesia, edited by Michael R. Allen, 10534. Sydney: Academic Press Australia.

Allen, Michael R. 1984. "Elders, Chiefs and Big Men: Authority, Legitimation and Political Evolution in Melanesia." American Ethnologist 11 (1): 20-41.

Banivanua-Mar, Tracey. 2007. Violence and Colonial Dialogue: The Australia-Pacific Labor Trade. Honolulu: University of Hawai'i Press.

Bennett, Judith A. 2016. "No Bali Ha'i: New Hebrides." In Mothers' Darlings of the South Pacific: The Children of Indigenous Women and U.S. Servicemen, World War Two, edited by Judith A. Bennett and Angela Wanhalla, 118-145. Honolulu: University of Hawai'i Press.

Bennett, Judith A., and Angela Wanhalla, eds. 2016. Mothers' Darlings of the South Pacific: The Children of Indigenous Women and U.S. Servicemen, World War Two. Honolulu: University of Hawai'i Press.

Besnier, Niko, and Kalissa Alexeyeff, eds. 2014. Gender on the Edge. Transgender, Gay and other Pacific Islanders. Honolulu: University of Hawai'i Press.

Bougainville, Louis de. 1772 [1967]. A Voyage Round the World. Translated from the French by Johann Reinhold Forster. London: J. Nourse and T. Davies. Fascimile edition in Bibliotecha Australiana No. 12, 1967. Amsterdam and New York: N. Israel and Da Capo Press.

Camacho, Keith. 2011. Cultures of Commemoration: The Politics of War, Memory and History in the Mariana Islands. Honolulu: University of Hawai i Press.

Camacho, Keith, and Setsye Shigematsu, eds. 2010. Militarized Currents: Toward a Decolonized Future in Asia and the Pacific. Minneapolis: University of Minnesota Press.

Connell, R. W. 1987. Gender and Power: Society, the Person and Sexual Politics. Stanford, CA: Stanford University Press.

Connell, R. W., and James Messerschmidt. 2005. "Hegemonic Masculinity: Rethinking the Concept." Gender \& Society 19 (6): 829-859.

Dening, Greg. 1996. Performances. Chicago: Chicago University Press.

Dinnen, Sinclair. 2001. Law and Order in a Weak State: Crime and Politics in Papua New Guinea. Honolulu: University of Hawaii i Press.

Douglas, Bronwen, and Chris Ballard. 2008. Foreign Bodies: Oceania and the Science of Race 17501940. Canberra: ANU E Press. Accessed 3 March 2015. http://press.anu.edu.au?p $=53561$

Dvorak, Gregory. 2008. “'The Martial Islands’: Making Marshallese Masculinities between American and Japanese Militarism." In Re-membering Oceanic Masculinities. Special issue of The Contemporary Pacific, edited by Margaret Jolly, 20 (1): 55-86.

Eriksen, Annelin. 2008. Gender, Christianity and Change in Vanuatu. An Analysis of Social Movements in North Ambrym. Farnham, UK: Ashgate Publishers. 
Ferguson, Kathy E., and Phyllis Turnbull. 1999. Oh, Say, Can You See? The Semiotics of the Military in Hawai i. Minneapolis, MN: University of Minnesota Press.

Forster, Johann Reinhold. 1996. Observations Made During a Voyage Round the World, on Physical Geography, Natural History and Ethic Philosophy, edited by Nicholas Thomas, Harriet Guest, and Michael Dettelbach. Honolulu: University of Hawai'i Press. New edition of John Reinhold Forster. 1778. Observations Made During a Voyage Round the World, on Physical Geography, Natural History and Ethic Philosophy. London.

Forster, George. 2000. A Voyage Round the World, edited by Nicholas Thomas and Oliver Berghof, assisted by Jennifer Newell. Honolulu: University of Hawai'i Press. New edition of Forster, Georg. 1777. A Voyage Round the World in His Britannic Majesty's Sloop Resolution. London: B. White.

Forsyth, Miranda. 2009. A Bird that Flies with Two Wings: Kastom and State Justice Systems in Vanuatu. Canberra: ANU E Press. Accessed 24 April 2015. http://press.anu.edu.au? $\mathrm{p}=49351$

Fry, Greg, and Tarcisius Tara Kabutaulaka, eds. 2008. Intervention and State Building in the Pacific. The Legitimacy of Co-operative Intervention. Manchester: Manchester University Press.

George, Nicole. 2008. "Contending Masculinities and the Limits of Tolerance." In Re-membering Oceanic Masculinities. Special issue of The Contemporary Pacific, edited by Margaret Jolly, 20 (1): 163-189.

Goodyear-Ka'ōpua, Noelani, Ikaika Hussey, and Erin Kahunawaika'ala Wright. 2014. A Nation Rising: Movements for Life, Land and Sovereignty. Durham, NC: Duke University Press.

Hess, Sabine. 2009. Person and Place. Ideas, Ideals and Practice of Sociality on Vanua Lava, Vanuatu. Person, Space and Memory in the Contemporary Pacific, vol. 2. Oxford: Berghahn.

Hokowhitu, Brendan. 2004. "Tackling Māori Masculinity: A Colonial Genealogy of Savagery and Sport." The Contemporary Pacific 16 (2): 259-284.

Hokowhitu, Brendan. 2008. 'The Death of Koro Paka: 'Traditional' Maori Patriarchy.' In Re-membering Oceanic Masculinities. Special issue of The Contemporary Pacific, edited by Margaret Jolly, 20 (1): 115-141.

Jolly, Margaret. 1987. "The Forgotten Women: A History of Migrant Labour and Gender Relations in Vanuatu." Oceania 58 (2): 119-139.

Jolly, Margaret. 1991. "Soaring Hawks and Grounded Persons: The Politics of Rank and Gender in North Vanuatu." In Big Men and Great Men: Personifications of Power in Melanesia, edited by Maurice Godelier and Marilyn Strathern, 48-80. Cambridge: Cambridge University Press.

Jolly, Margaret. 1992. "Ill-natured Comparisons': Racism and Relativism in European Representations of ni-Vanuatu from Cook's Second Voyage." History and Anthropology 5 (3-4): 331-364.

Jolly, Margaret. 1994. Women of the Place: Kastom, Colonialism and Gender in Vanuatu. Chur and Reading: Harwood Academic Publishers.

Jolly, Margaret. 1996. "Devils, Holy Spirits, and the Swollen God: Translation, Conversion and Colonial Power in the Marist Mission, Vanuatu, 1887-1934." In Conversion to Modernities: The Globalization of Christianity, edited by Peter van der Veer, 231-262. New York and London: Routledge.

Jolly, Margaret. 2008a. "Introduction. Moving Masculinities: Memories and Bodies across Oceania." In Re-membering Oceanic Masculinities. Special issue of The Contemporary Pacific, edited by Margaret Jolly, 20 (1): 1-24.

Jolly, Margaret, ed. 2008b. "Re-membering Oceanic Masculinities." The Contemporary Pacific 20 (1). Jolly, Margaret. 2009a. "Revisioning Gender and Sexuality on Cook's Voyages in the Pacific." In James Cook und die Entdeckung der Sudsee/James Cook and the Exploration of the Pacific, edited by Robert Fleck and Adrienne L. Kaeppler, 98-102. Bonn: Kunst-und Ausstellungshalle der Bundesrepublik Deutchsland, English version, Thames and Hudson. 
Jolly, Margaret. 2009b. "The Sediment of Voyages: Re-membering Quirós, Bougainville and Cook in Vanuatu." In Oceanic Encounters: Exchange. Desire, Violence, edited by Margaret Jolly, Serge Tcherkézoff, and Darrell Tryon, 57-111. Canberra: ANU E Press. Accessed 4 March 2015. http://press.anu.edu.au?p $=60461$

Jolly, Margaret. 2012. "Women of the East, Women of the West: Region and Race, Gender and Sexuality on Cook's Voyages." In The Atlantic World in the Antipodes, edited by Kate Fullagar, 2-32. Newcastle: Cambridge Scholars Press.

Jolly, Margaret. 2013. "Epilogue. Agreeing to Disagree about Kago." In Kago, Kastom and Kalja: Old Theories and New Realities in the Study of Melanesian Movements, edited by Marc Tabani and Marcellin Abong, 187-212. Marseille: Pacific-credo Publications.

Jolly, Margaret. 2015. "Braed Praes in Vanuatu: Both Gifts and Commodities." In Gender and Person in Oceania. Special Issue of Oceania, edited by Anna-Karina Hermkens, Rachel Morgain, and John Taylor, 85 (1): 63-78.

Kauanui, J. Kēhaulani. 1998. “Off-Island Hawaiians 'Making' Ourselves at 'Home.”' Migrating Feminisms: The Asia-Pacific Region. Special issue of Womens Studies International Forum, edited by Kalpana Ram and J. Kēhaulani Kauanui, 21 (6): 681-693.

Kauanui, J. Kēhaulani. 2008. Hawaiian Blood: Colonialism and the Politics of Sovereignty and Indigeneity. Durham, NC: Duke University Press.

Keesing, Roger. 1986. "Plantation Networks, Plantation Culture: The Hidden Side of Colonial Melanesia." Journal de la Société des Océanistes 42 (82-3): 163-170.

Kraemer, Daniela. 2013. Planting Roots, Making Place. An Ethnography of Young Men in Port Vila. $\mathrm{PhD}$ thesis, London School of Economics.

Layard, John. 1942. Stone Men of Malekula. London: Chatto and Windus.

Lightner, Sara, and Anna Naupa. 2005. Histri blong yumi long Vanuatu: An Educational Resource, vol. 3. Port Vila: Vanuatu Cultural Centre.

Lindstrom, Lamont. 1989. "Working Encounters: Oral Histories of World War II Labor Corps from Tanna, Vanuatu." In The Pacific Theatre: Island Representations of World War II, edited by Geoffrey White and Lamont Lindstrom, 395-416. Pacific Island Monograph Series, No 8. Honolulu: University of Hawai'i Press, Center for Pacific Island Studies.

Lindstrom, Lamont. 1990. Knowledge and Power in a South Pacific Society. Washington and London: Smithsonian Institution Press.

Lindstrom, Lamont. 1993. Cargo Cult: Strange Stories of Desire from Melanesia and Beyond. Honolulu: University of Hawai i Press.

Lindstrom, Lamont, and James Gwero, eds. 1998. Big Wok: Storian blong Wol Wo Tu long Vanuatu. Christchurch and Suva: Macmillan Brown Centre for Pacific Studies and Institute of Pacific Studies, University of the South Pacific.

Lindstrom, Lamont, and Geoffrey M. White. 1990. Island Encounters: Black and White Memories of the Pacific War. Washington and London: Smithsonian Institution Press.

Lusby, Stephanie. n.d. "Securitization, Development and the Invisibility of Gender." In Transformations of Gender in Melanesia, edited by Martha Macintyre and Ceridwen Spark. Canberra: ANU Press. (Forthcoming).

MacClancy, Jeremy. 1980. To Kill a Bird with Two Stones: A Short History of Vanuatu. Port Vila: Vanuatu Cultural Centre.

Macintyre, Martha. 2008. "Police and Thieves, Gunmen and Drunks: Problems with Men and Problems with Society in Papua New Guinea." In Changing Pacific Masculinities. Special Issue of The Australian Journal of Anthropology, edited by John P. Taylor, 19 (2): 179-193.

McDonnell, Siobhan. 2015. “The land will eat you': land and sorcery in North Efate, Vanuatu." In Talking it Through: Responses to Sorcery and Witchcraft Beliefs and Practices in Melanesia, edited by Miranda Forsyth and Richard Eves, 137-160. Canberra: ANU Press. 
Moore, Clive. 1985. Kanaka: A History of Melanesian Mackay. Port Moresby: Institute of Papua New Guinea Studies and University of Papua New Guinea Press.

Sahlins, Marshall. 1985. Islands of History. Chicago: University of Chicago Press.

Shineberg, Dorothy. 1999. The People Trade: Pacific Island Laborers and New Caledonia, 1865-1930. Honolulu: University of Hawai'i Press.

Smith, Bernard. 1985 [1960]. European Vision and the South Pacific, 1768-1850. 2nd ed. Sydney: Harper and Rowe.

Smith, Vanessa. 2010. Intimate Strangers: Friendship, Exchange and Pacific Encounters. Cambridge: Cambridge University Press.

Tabani, Marc. 2008a. Une pirogue pour le paradis: le culte de John Frum à Tanna. Paris: Maison des Sciences de L'Homme.

Tabani, Marc. 2008b. “A political history of Nagriamel on Santo, Vanuatu." Oceania 78 (3): 332-357.

Tabani, Marc, and Marcelin Abong, eds. 2013. Kago, Kastom and Kalja: Old Theories and New Realities in the Study of Melanesian Movements. Marseille: Pacific-CREDO Publications.

Tattevin, Elie. 1926-27. "Sur les bords de la mer sauvage." Revue d'Histoire des Missions 3: 370-413, 4: 82-97, 407-429, 557-579.

Taylor, John P. 2008a. The Other Side: Ways of Being and Place in Vanuatu. Honolulu: University of Hawai'i Press.

Taylor, John P. 2008b. “Changing Pacific Masculinities: The 'Problem' of Men.” In Changing Pacific Masculinities. Special Issue of The Australian Journal of Anthropology, edited by John P. Taylor, 19 (2): 125-135.

Taylor, John P. 2010. "The Troubled Histories of a Stranger God: Religious Crossing, Sacred Power and Anglican Colonialism in Vanuatu." Comparative Studies in Society and History 52 (2): 418-446.

Taylor, John P. 2016. "Two Baskets Worn at Once: Christianity, Sorcery and Scared Power in Vanuatu." In Christianity, Conflict and Renewal in Australia and the Pacific, edited by Fiona Magowan and Carolyn Schwarz, 139-160. Leiden: Brill.

Tcherkézoff, Serge. 2003. "A Long and Unfortunate Voyage Towards the 'Invention' of the Melanesia/Polynesia Distinction 1595-1832.” In Dumont d'Urville's Divisions of Oceania: Fundamental Precincts or Arbitrary Constructs?' Special issue of Journal of Pacific History, edited by Geoffrey Clark, 38 (2): 175-196.

Tcherkézoff, Serge. 2008. Polynesie/Melanesie: linvention française des "races » et des régions de l'Océanie. Papeete, Tahiti: Au Vent des Iles.

Teaiwa, Teresia K. 2014. "Same Sex, Different Armies: Sexual Minority Invisibility among Fijians in the Fiji Forces and British Army." In Gender on the Edge: Transgender, Gay and Other Pacific Islanders, edited by Niko Besnier and Kalissa Alexeyeff, 266-292. Honolulu: University of Hawai'i Press.

Tengan, Ty P. Kāwika. 2008a. Native Men Remade. Gender and Nation in Contemporary Hawai i. Durham: Duke University Press.

Tengan, Ty P. Kāwika. 2008b. 'Re-membering Panalāau: Masculinities, Nation and Empire in Hawai'i and the Pacific.' In Re-membering Oceanic Masculinities. Special issue of The Contemporary Pacific, edited by Margaret Jolly, 20 (1): 27-53.

Tengan, Ty P. Kāwika. 2016. "The Mana of Kū: Indigenous Nationhood, Masculinity and Authority in Hawai' $i$ '” In New Mana, edited by Matt Tomlinson and Ty P. Kawika Tengan, 55-75. Canberra: ANU Press.

Tengan, Ty P. Kāwika, and Jesse Makani Markham. 2009. "Performing Polynesian Masculinities in American Football: From 'Rainbows to Warriors." The International Journal of the History of Sport 26 (16): 2412-2431.

Trask, Haunani-Kay. 1999 [1993]. “From a Native Daughter." In From a Native Daughter: Colonialism and Sovereignty in Hawai $i$. rev ed. Honolulu: A Latitude 20 Book, University of Hawai'i Press, 1999. 
Walker, Isaiah. 2005. "Terrorism or Native Protest? The Hui 'O He'e Nalu and Hawaiian Resistance to Colonialism." Pacific Historical Review 74 (4) (2005): 575-595.

White, Geoffrey. 2001. "Public History and Globalization. Ethnography at the US Arizona Memorial Pearl Harbour." Cultural Resource Management 24 (5): 9-13.

White, Geoffrey. 2004. "National Subjects. September 11 and Pearl Harbor." American Ethnologist 31 (3): 241-254.

\section{Visual References}

Born of Conflict: Children of the Pacific War. 2013. Produced by Steven R. Tolley, Judy Bennett and Peggy Holter. University of Otago and Two Shores Limited. https://www.youtube.com/watch? $\mathrm{v}=2$ CsFxxnJFnw

Hodges, William The Landing at Erromanga, One of the New Hebrides. Engraving by William Sherwin after Hodges. 1774.

Webber, John The Death of Cook. Oil Painting c. 1782. Original National Maritime Museum Greenwich. Engraved by Francesco Bartolozzi and William Byrne 1784. Dixon Library State Library of New South Wales. 